\title{
Kateketutdanning - i går, i dag, i morgon
}

\section{Av Eldbjørg Leinebø Ekre}

Kva må ein kunne for å vere kateket, og korleis kan ein få den naudsynte kunnskapen? Kva er det screigne med katekettenesta, og kva skil den frå dei andre kyrkjelege profesjonane? Utgangpunktet for spørsmåla og refleksjonane i denne artikkelen er arbeidet med å etablere ein ny erfaringsbasert master $i$ kyrkjeleg undervisning ved MF Vitenskapelige høyskole. Arbeidet starta hausten 2017, med oppstart av det første kullet hausten 2018. Underteikna har leia prosjektgruppa som har arbeida fram den nye masteren. ${ }^{1}$

I utviklingsarbeidet var det sentralt å byggje vidare på tidlegare erfaringar med kateketutdanning, og i scerleg grad erfaringane med kateketutdanningane ved MF. Samstundes var det behov for å tenkje nytt. Utviklingsarbeidet støtta seg på gamle studieplanar, evalueringsrapportar, nyare forsking om undervisningstenesta i Dnk, sakshandsaming og vedtak $i$ Kyrkjerådet, og tenesteordning og kvalifikasjonskrav for kateketar.

I denne artikkelen vil eg ta eit raskt attendeblikk på nokre utdanningshistoriske liner innan kateketutdanning sidan Lov om katekettenesta vart vedteke i 1969. Vidare vil eg sjå på grunnlaget for og innhaldet $i$ kateketutdanninga slik den er i dag, for så å peike på nokre utfordringar for kateketutdanninga både i dag og i framtida.

ELDbJøRG LeINEBø EKRE. Seniorrådgjevar ved KA - Arbeidsgiverorganisasjon for kirkelige virksomheter, tidlegere rådgjevar ved IKO-Kirkelig pedagogisk senter. Kateket og lœrar. E-post: eldbjorg.ekre@ka.no

\section{FraMVEKSTEN AV KATEKETTENESTA}

Ved lov om kateketteneste av 19. juni 1969 i Stortinget vart dei fyrste kateketstillingane oppretta. Men sjølv om katekettenesta er forholdsvis ny i Den norske kyrkje, har dåpsopplæring stått sterkt i norsk luthersk tradisjon. Martin Luther var oppteken av kor viktig det var å formidle grunnleggjande kristen kunnskap til folket, og ifylgje kyrkjeordninga av 1539 for Danmark-Noreg skulle presten ha ein halvtime med innføring i barnelærdomen i gudstenesta i tillegg til preika. Dersom det var vanskeleg å samle folket regelmessig til kyrkje, kunne han reise rundt i soknet på ein vekedag og samle folket til katekismeundervisning. Undervisning har alltid vore ein del av presten sitt virke, og er det også i dag.

1 Prosjektgruppa besto i tillegg av seniorrådgjevar Mona Gulbrandsen Bø (sekretær), universitetslektor Astrid Sandsmark og universitetslektor Hanne Birgitte Sødal Tveito. Studiedirektør Hilde Brekke Møller deltok i delar av arbeidet, og studieprogrammet vart og lagt fram for eit utval undervisningsrådgjevarar ved bispedømekontora, og for KUFO - Kirkelig undervisningsforbund. 
Med Lov om konfirmasjon i 1736 fekk ein for første gang ei ordna opplæring av alle døypte, og allmugeskulen frå 1739 hadde i byrjinga kristendom som hovudfag. I allmugeskulen var klokkaren lærar, men etter kvart vart dei fyrste lærarane tilsette, og fag som lesing, skriving og rekning kom til. Folkeskulelova i 1889 markerte overgangen frå kyrkjeleg allmugeskule til borgarleg folkeskule, likevel tok det lang tid før dåpsopplæring og særleg konfirmasjonsopplæring var ute av skulen. Ved Lov om grunnskulen i 1969 vart det slått fast at skulen sin kristendomsundervisning ikkje var kyrkja si dåpsopplæring. Det vart sett i gang prosessar for at kyrkja kunne ta ansvaret for dåpsopplæringa, og Lov om kateketteneste i 1969 var såleis starten på ei ordna undervisningsteneste i Dnk. Det var særleg kyrkjelydar med store konfirmantkull som fekk tildelt kateket dei fyrste åra.

I byrjinga hadde kateketane eit særleg ansvar for konfirmantundervisning, ungdomsarbeid og studiearbeid for vaksne. Utover 70-80-talet vart det oppretta fleire statlege og kommunale kateketstillingar, i 1995 hadde ein rundt 200 kateketstillingar. Opprettinga av katekettenesta ga undervisningsarbeidet i kyrkja eit fagleg løft, og framveksten og utviklinga av katekettenesta har hatt mykje å seie for pedagogisk utviklingsarbeid i kyrkjelydane.

Dei fyrste kateketane var som regel lærarar av utdanning. Men det er skilnad på å vere lærar i skulen og lærar i kyrkja, og behovet for ei kateketutdanning vaks fram. Bispemøtet satte i 1970 ned ein komité for å arbeide med planar for eit «kateketpraktikum», og i 1977 vart Kateketseminaret oppretta ved Menighetsfakultetet. Kateketseminaret var ei eittårig praktisk-kateketisk utdanning som var vanleg å ta etter anna utdanning, dei fleste hadde lærarutdanning eller annan pedagogisk utdanning i botn. I 1985 oppretta distriktshøgskulen i Volda ei fireårig profesjonsutdanning til kateket.

Fyrst i 1987 vart eittårig praktisk-kateketisk utdanning obligatorisk for tenesta. Som ein konsekvens av dette blei det i åra 1987-89 arrangert vidareutdanningskurs for kateketar i teneste, dei såkalla KIT-kursa. Kursa vart gjennomført i samarbeid mellom Kateketforeininga, Menighetsfakultetet og distriktshøgskulen i Volda.

I takt med utviklinga i samfunnet og kyrkja sine behov har dei formelle kompetansekrava til kateket i løpet av dei 50 åra vore i endring. Bispemøtet sa i 1967 fylgjande om utdanningskrav til dei nye kateket-stillingane: «Som utdannelse for kateketstilling bør for eksempel kunne aksepteres forskjellige pedagogiske utdannelser som omfatter enten kristendom som mellomfag eller hovedfag». (Kirkerådet, 2002 s.2).

Sjølv om det i oppstarten ikkje var noko krav om praktisk-kateketisk utdanning, viser det seg at innhaldsmomenta i dei ulike utdanningsprogramma har vore ganske eintydige. Pedagogikk, kristendom/teologi og praktisk-kateketiske fag har vore, og er, dei tre sentrale byggjesteinane i ei kateketutdanning. 
Som ein fylgje av utdanningsreforma i heile utdanningssystemet tidleg på 2000-talet, blei det vurdert kva konsekvensar det ville få for kateketutdanninga. Frå Kyrkjerådet blei tre skisser teikna ut: Ei 3-årig eller ei 4-årig utdanning på bachelor-nivå, eller eit 5-årig program på masternivå. Etter omfattande høyring vart det gjort vedtak i Kyrkjemøtet i 2004 om krav til master for å bli kateket, noko som førte til at utdanninga måtte leggjast om for å kome masterkravet i møte. ${ }^{2}$ Eit av hovedargumenta var at for å leie undervisningstenesta i Dnk var det viktig å ha god fagleg tyngde, og vere på same utdanningsnivå som prestar og diakonar. Dessutan låg Trusopplæringsreforma i emning, og ein såg føre seg auka behov for kvalifiserte kateketar som kunne leie undervisningstenesta $\mathrm{i}$ større fellesråd/prosti-område.

Med trusopplæringsreforma som kom i 2004, har det på 15 år vore ei firedobling i antall nye undervisningsstillingar i Dnk. Av ca. 800 undervisningsstillingar (mange er deltidsstillingar) har ca. 200 av desse tittelen kateket. Dei to andre etablerte stillingskategoriane innan undervisning i Dnk i dag er kyrkjelydspedagog og kyrkjelydsarbeidar. ${ }^{3}$ Fleire utdanningsinstitusjonar tilbyr i dag bachelor-program som utdannar til kyrkjelydspedagog.

\section{KATEKETUTDANNING I GÅR \\ Kateketseminaret ved Menighetsfakultetet}

Kateketseminaret ved MF vart oppretta i 1977, og Aasmund Dale var den fyrste rektoren. Dale blir sett på som ein pioner i arbeidet med å fremje den kyrkjelege undervisninga i Dnk. Det gjaldt arbeid med fagbøker og pedagogisk undervisningsmateriell, sentralkyrkjelege dokument og program for dåpsopplæring, og det gjaldt arbeidet på MF med å utvikle kateketutdanninga og dei kateketiske studieemna. ${ }^{4}$

2 Kvalifikasjonskravene ble behandlet av KM2002:KM 6/02 «Kvalifikasjonskrav for kateketer, diakoner og kanhtorer. https://kirken.no/globalassets/kirken.no/migrering/vedtak497.pdf. Oppfølging i sakene KR 14/03,15/03 og 16/03 "Kvalifikasjonskrav for kateketer/diakoner/kantorer", som resulterte i vedtaket i 2004, som er selve tjenesteordningen. https://kirken.no/nb-NO/om-kirken/slik-styres-kirken/kirkemotet/dokumenter_vedtak/kirkemotet-15.11.2004---20.11.2004-bodo/

3 Då trusopplæringsreforma kom i 2003, vart det frå sentralt hald opna opp for å tilsette personell med ulik kompetanse i undervisningsstillingar, noko som resulterte i eit mylder av titlar på dei tilsette innan undervisning. Det var titlar som trusopplæringsleiar, trusopplærar, trusopplæringsmedarbeidar, undervisningsleiar, prosjektleiar, kyrkjelydspedagog m.m. Med Kyrkjemøtesaka frå 2015 landa denne saka med vedtak om tre stillingstitlar innan kyrkjeleg undervisning: kateket, kyrkjelydspedagog og kyrkjelydsarbeidar, Til kyrkjelydsarbeidar er det ingen formelle kompetansekrav, for tilsetjing som kyrkjelydspedagog krev ein bachelor som inkluderar minimum 30 stp. pedagogikk og 30 stp. kristendom/teologi.

4 Dale var engasjert i ei rekke verv innan kyrkjeleg undervisning og religionspedagogikk både i innland og i utland. Han hadde blant anna bakgrunn som teolog, religionspedagog og leiar ved IKO, som lærar i kateketiske fag ved praktikum på MF, og som redaktør av Prismet i perioda 1970-1984. Han ga ut fagbøker, undervisningsmateriell og artiklar. Ein klassikar som er å finne i eitkvart religionspedagogisk bibliotek er læreboka Laring i kirken: en praktisk kirkedidaktikk. Dale stod og bak UPRO-programmet (Undervisningsprogram for hjem og kirke), som vart lagt fram av IKO i 1970. Programmet danna grunnlag for utvikling av pedagogisk undervisningsmateriell ved IKO, og tankegodset vart også nedfelt i Plan for dåpsopplæring i den norske kyrkje frå 1991 og eit grunnlag for NOU 2000:26 Til et åpent liv i tro og tillit. 
I studieplanen frå 1992, som er tilgjengeleg på MF sine nettsider, står det fylgjande: «Kateketseminaret gir den praktisk-kateketiske utdanningen som er nødvendig for å bli fast tilsatt som kateket, altså en kirkelig yrkeskompetanse.» Vidare står det skildra om kateketen: «Kateketen er undervisningsleder $i$ menigheten og har som sitt scerlige ansvar å fremme og gjennomføre et undervisnings- og lederfostringsarbeid blant barn, unge og voksne. Kateketens oppgaver er så spesielle at det trengs en egen utdanning, der kateketen blir kjent med oppgavene og får trening $i$ å løse dem på en måte som er både teologisk og pedagogisk forsvarlig.». Inntakskravet til utdanninga var kristendom grunnfag og to år med annan høgare utdanning. Dersom søkar ikkje hadde pedagogikk i fagkretsen, fekk ein tilbod om pedagogisk forkurs. Ved gjennomført kateketseminar vart delar av utdanninga godkjent som del av den praktisk-pedagogiske utdanninga ved pedagogisk seminar. Dette var ein føremon for kateketar som ynskja kvalifikasjon også som lærar i skulen. (Fagplan frå 1992, s.2).

Tanken om at katekettenesta spring ut av ei lærarutdanning, ser vi tydelege spor etter i fagplanen frå 1992. Eit av dei fem emna studentane skal fordjupe seg i, er generell pedagogikk og religionspedagogikk med vekt på undervisning innanfor skuleverket. Undervisning og oppseding i barnehagen var og tema innanfor dette emnet. I tillegg hadde studentane praksis i ulike skuleslag. Eit anna hovudemne var å dyktiggjere til å undervise i ei kyrkjeleg ramme, og å utvikle kompetanse til å vere undervisningsleiar i kyrkjelyden. Vidare var det tre andre hovudtema: Kyrkja i samfunnet (kyrkjerett, leiing, administrasjon, kyrkje og organisasjonskunnskap, yrkesetikk og sjølvforståing), kristen forkynning og sjelesorg (liturgikk, homiletikk, kateketisk forkynning, praktiske øvingar) , og praksis med øving og vegleiing på fleire kateketiske områder. (Fagplan frå 1992, s.3).

Undervisninga var tverrfagleg, dvs. den praktiske bruken av faga skulle gå på tvers av tradisjonelle faggrenser, og i vekselverknad mellom teori og praksis, teologi og pedagogikk. Kateketseminaret var tverrfagleg også i den forstand at delar av undervisninga var saman med presteseminaret eller med andre faggrupper ved fakultetet.

\section{Ei fireårig kateketutdanning i Volda}

Frå lov om katekettenesta kom i 1969, tok det heile 16 år før det vart oppretta ei rein kateketutdanning, denne var ved dåværande distriktshøgskulen i Volda og i samarbeid med Volda lærarhøgskule. Utdanninga gjekk over 4 år, vart oppretta i 1985, og i 1989 vart dei fyrste kateketane uteksaminerte. Undervisninga skjedde i samvirke mellom fagmiljøet ved kyrkjefagavdelinga ved Distriktsh $\emptyset$ gskulen og det pedagogiske miljøet ved Lærarhøgskulen. Denne utdanninga var eit heilskapleg utdanningsl $\varnothing \mathrm{p}$ der sosialiseringa til ein tydeleg kateketidentitet var lagt vekt på. Det var viktig å meisle ut kateketen si rolle og tenestemessige 
plass i det kyrkjelege landskapet. Tilsette ved kyrkjefagavdelinga deltok aktivt i å utvikle kateketyrket og den kyrkjelege undervisninga i si samtid. Utdanninga ga ei kvalifisering til både kateket og lærar. Kateketutdanninga var samansett av kristendomskunnskap mellomfag, pedagogikk grunnfag, eit valfritt undervisningsfag (gjerne praktisk-estetisk fag), og praktisk-kyrkjeleg årseining. Den praktisk-kyrkjelege årseininga låg $\mathrm{i}$ innhald tett opp til kateketseminaret ved MF. Det var ca. 8-10 studentar i kullet på kateketutdanninga i Volda. På grunn av sviktande søkjargrunnlag og nye kompetansekrav frå 2004, vart utdanninga lagt ned i $2003 .^{5}$

\section{KATEKETUTDANNing I DAg}

\section{Kateketutdanning ved TF, VID og NLA}

Det er i dag mogleg å ta master som kvalifiserar til kateket ved fleire lærestadar. Det er tilbod om ein slik master ved NLA Høgskulen i Bergen og ved Det Teologiske Fakultet (TF) ved Universitetet i Oslo. Dei tilbyr master i teologi med vekt på kyrkjeleg undervisning. Kyrkjeleg utdanningssenter i Nord (VID) tilbyr kateketiske studieemner på masternivå som ein kan integrere i masterprogram som kvalifiserar til kateket ved MF og ved Universitet i Bodø.

Mange søkjer seg til kateketutdanning etter ei lærarutdanning, ei anna pedagogisk utdanning eller ein annan relevant bachelor. Dette er mogleg på grunn av dei fleksible kvalifikasjonskrava i tenesteordninga. Det er ikkje rom for å gå vidare inn på alle desse utdanningsprogramma i denne artikkelen, da utgangspunktet for denne artikkelen er arbeidet med erfaringsbasert master ved MF.

\section{Disiplinbasert master i kyrkjeleg undervisning ved MF}

Då masterkravet kom i 2005, vart kateketpraktikum ved MF lagt ned, og disiplinbasert master i kyrkjeleg undervisning vart etablert. Ny tenesteordning og kvalifikasjonskrav for kateket frå 01.01.2005 la dei viktige føringane i å forme ei ny kateketutdanning. Kateketen skulle som før vere leiar av undervisningstenesta i kyrkjelyden, medan rammene for innhaldet i tenesta vart meir fleksible. Den verkeleg store endringa var dei nye kvalifikasjonskrava med krav om mastergrad i utdanninga. Dei nye utdanningskrava førte til at kateketutdanninga måtte leggjast om på heile lina.

Ved MF vaks det fram, under Heid Leganger-Krogstad si leiing, eit masterprogram i kyrkjeleg undervisning som var fleksibelt i forma. Det måtte det vere for å kunne handtere to ulike studentgrupper, heiltidsstudenten og deltids-/ fjernstudenten. Heiltidsstudentar tok kateketutdanning som grunnutdanning, deltidsstudenten var ofte studentar som tok master som «second career», og

5 Referanse, Magnar Hjertenæs, høgskulelektor ved Høgskulen i Volda 
skulle byggje vidare på ei lærarutdanning eller annan pedagogisk utdanning. Fleire kateketar med utdanning på bachelor-nivå nytta høvet til å ta den nye masteren. I perioda 2004-2008 har MF uteksaminert 53 studentar med master i kyrkjeleg undervisning.

Masterkravet styrka den kyrkjelege undervisninga som fagområde, noko som har kome heile kyrkja til gode. Leganger-Krogstad var og sentral i arbeidet med praksisnær forsking. Gjennom utdanningsprogrammet har studentane sine masteroppgåver vore viktige religionspedagogiske bidrag, og fleire har bidrege med artiklar i ulike tidsskrift. På denne måten har masterstudentane sjølve vore med på å drive fram kyrkjeleg undervisning som fagområde.

I det femårige masterprogrammet til kateket var PPU (Praktisk-pedagogisk utdanning) med praksis i både skule og kyrkje, ein viktig del av utdanninga. Dette ga fagleg tyngde og breidde i forståinga av metodisk og didaktisk arbeid både i kyrkje og i skule. Det var eit bærande prinsipp i heile utdanninga at studentane skulle få ei pedagogisk, teologisk og praktisk-kateketisk utdanning, med kvalifikasjon til arbeid både i kyrkje og i skule. ${ }^{6}$

På slutten av 80-talet/byrjinga av 90-talet var det om lag 2-5 studentar per år på kateketutdanninga. Antall søkjarar til kateketutdanninga var også med innføring av masterkravet i 2004 forholdsvis lavt. Tenkinga kring «dobbeltkvalifikasjon» til arbeid både i skule og kyrkje, var stadig under press, blant anna på grunn av lavt studenttal. Med omleggjing av lærarutdanninga til femårig masterprogram, auka presset på den femårige kateketutdanninga ved MF. Grunnutdanninga til kateket er frå hausten 2019 lagt om, der bachelor og master med teologiske, kateketiske og kyrkjelydspedagogiske fag utgjer dagens fulltidsutdanning til kateket ved MF. Dette er ei rein kyrkjeleg utdanning som kvalifiserar til kateket, men og til arbeid i kristne organisasjonar.

Denne omleggjinga representerer eit brot med tidlegare tenking kring kateketutdanning, men det er og ei erkjenning og ein konsekvens av at utdanning, samfunn og kyrkje er i endring.

\section{Erfaringsbasert master ved MF}

Målgruppa for erfaringsbasert master i kyrkjeleg undervisning er studentar som ynskjer å bli kateket som «second career». Utdanninga er på deltid, samlingsbasert, og går over tre år. Utdanninga har praktisk-kateketiske studieemner og teologiske fag på til saman 90 studiepoeng. Opptakskravet er utdanning som tilsvarar bachelor med minimumskrav innan pedagogikk og kristendom/teologi. Hausten 2019 er det til saman 26 studentar i dette utdanningsprogrammet.7

6 Sentrale i arbeidet med å utvikle den nye masteren var Kristine Aksøy og Heid Leganger-Krogstad. Aksøy var tilsett som programleiar ved kateketseminaret frå 1999-2004, og Leganger-Krogstad var programleiar ved den nye kateketutdanninga frå 2004-2017

7 Referanse, MF v/Mona Gulbrandsen Bø 
Dei fleste tek heile masterprogrammet, nokre få tek enkeltemner. Dei fleste av studentane har lærarutdanning eller annan pedagogisk utdanning i botn.

Kateketyrket er ei mangfaldig teneste, og tenesteordninga gjev heller overordna rammer og føringar for katekettenesta, enn detaljerte skildringar. Dei fleksible kvalifikasjonskrava gjer det mogleg å justere kateketutdanninga i møte både med samfunnsutvikling og dei kyrkjelege behov på ein god og relevant måte. Kateketyrket er ei yrkesretta masterutdanning som dyktiggjer til både ei spissa og ei brei teneste i Dnk. Tenesta krev kunnskap og ferdigheiter på fleire fagområder, og er difor sett saman av mange ulike komponentar og fag. Oppbygginga av ei kateketutdanning er ikkje eintydig, og det er styrande for innhaldet i utdanninga om ein tek kateketutdanning som «second career», eller vel eit femårig utdanningsprogram som førar fram til kateket.

Studiet sine hovudemne er bibelteologi (GT og NT), truslære/dogmatikk, kyrkja som lærande fellesskap/læringsteori, pedagogisk planarbeid/leiing, sjelesorg og diakoni i møte med barn, unge og familier, kyrkjebygg, liturgi og gudsteneste, vegleia praksis og masterarbeid.

Styrka til ein erfaringsbasert master er ofte samspelet mellom fagstoffet og den mangfaldige utdanningsbakgrunnen og yrkespraksisen til studentane. I mellomrommet mellom teori og praksis skjer det verdifull læring. $\AA$ utveksle erfaringar med utgangspunkt i forskjellige faglege tradisjonar, kan og vere med på å utvikle det praktisk-kateketiske faget.

\section{KATEKETYRKET - EI MANGFALDIG TENESTE}

Å arbeide med barn og unge i dag kan vere utfordrande på mange plan. Samfunnet endrar seg raskt, og det gjer barne- og ungdomskulturen også. Kunnskap om barn og unge blir raskt gamal kunnskap. Mange kateketar fortel om ei undervisningsteneste i endring, der dei diakonale og sosialpedagogiske behova aukar. Det er mykje som talar for at det kan vere behov for å styrkje kateketane sin kunnskap om fag som spesialpedagogikk, sosialpedagogikk, sjelesorg og diakoni, særleg i møte med sårbare barn og unge. I eit omsorgsperspektiv er det og sentralt å reflektere over kva det er i trusopplæringa som gjev hjelp til livstolking og livsmestring.

Ei utfordring for mange kateketar har vore å finne sin plass i det kyrkjelege landskapet. Fleire fortel om krysspress mellom eigne og andre sine forventningar. Dette er ei utfordring kateketane deler med andre faggrupper i kyrkjestaben. Tenesteordningane legg delvis opp til overlappande oppgåver mellom dei ulike kyrkjelege profesjonane. Vi kan nemne gudstenestlege funksjonar, forkynning, konfirmantundervisning, omsorgsarbeid og sjelesorg. Dette gjer at tverrfagleg tenking, samarbeid og respekt blir viktig for å lukkast. Kateketane har, som alle andre yrkesgrupper, behov for ein fagleg forankring og ein tydeleg yrkesiden- 
titet. Fleire kateketar har tatt leiarutdanning for å dyktiggjere seg i si faglege leiing som kateket. Dersom lærestadane skal lukkast med å gje relevant undervisning til kyrkjeleg undervisning som fagområde, må dei ha sterke fagmiljø med kunnskap og kjennskap til katekettenesta sin kompleksitet. Utdanninga må vere solid forankra i ein teologisk, pedagogisk og kateketisk tradisjon.

Danning til ein profesjon skjer gjerne i samkvem med andre. For å skape eit miljø for kateketstudentane, er det ved MF lagt opp til at studentane i det disiplinbaserte utdanningsprogrammet og studentane i det erfaringsbaserte programmet skal ha nokre felles studieemner. Det er og lagt opp til «profesjonssamlingar» der det sosiale er vektlagt, samstundes som det er eit rom for å ta opp avklaringar kring mellom anna rammer og roller for tenesta, yrkesidentitet og profesjon.

Det er i denne samanhengen verdt å nemne det vigslingsførebuande programmet VTVT (Vegen til vigsla teneste). Dette er ikkje ein del av kateketutdanninga, men er eit program i regi av Bispemøtet. Programmet starta i 2018, og er eit positivt supplement når det kjem til danning til kateketyrket, bruk av liturgiske klede, forståing av vigsling og biskopen sitt tilsyn, med meir.

\section{KATEKETUTDANNING I MORGON}

Det er i år 50 år sidan Lov om katekettenesta i Dnk vart vedteken. Vi kan sjå attende på 50 år med ei organisert undervisningsteneste, og 50 år med kateket.

Alt talar for at det vil vere stort behov for kateketar også i framtida. Eg vil avslutningsvis liste opp nokre (gamle og nye) utfordringar for kateketutdanninga som kyrkja og lærestadane må fortsette å arbeide med både i dag og i framtida.

- Lærarutdanninga er blitt eit femårig masterprogram. Dette utfordrar «lærarvegen» inn i kateketyrket. Utan rett fagkombinasjon i botn kan utdanningsløpet til kateket bli urimeleg langt. Det vil vere behov for at ungdomar som ynskjer å bli både lærar og kateket, får god og relevant rådgjeving på eit tidleg tidspunkt.

- Er den femårige grunnutdanninga til kateket truga? Tenesteordninga opnar opp for mange utdanningsvegar til kateket, til dømes er det fleire relevante masterprogram som blir godkjende. Ein kan sjå føre seg at kateketstudentane vil «navigere» seg fram til kateketyrket ved å velge andre utdanningsprogram som gjev kompetanse også til andre yrker, som til dømes ei lærarutdanning.

- Er det behov for ei sterkare styring i kva pedagogikk-faget skal innehalde? I dag har kateketar ein svært mangfaldig pedagogisk bakgrunn. Det kan vere småbarnspedagogikk, skulepedagogikk, praktisk-pedagogisk utdanning (PPU) eller kyrkjelydspedagogikk. Det kan vere ein føremon å halde på 
fleksibiliteten i innhaldet i pedagogikk-faget, men det er heller ikkje uvesentleg kva for pedagogikk den einskilde har studert.

- Det har vore mykje praksisbasert forsking på trusopplæring og kyrkjeleg undervisning som ein fylgje av trusopplæringsreforma. Det vil fortsatt vere viktig at kateketutdanning utviklar seg i eit samspel mellom forsking og praksis.

- På line med andre som arbeidar med barn og unge, er det i aukande grad behov for ei sosialfagleg tilnærming til dei unge. Kateketen treng kunnskap og gode verktøy for å vere profesjonell i yrket etter dagens krav og standard. Det vil vere behov for kompetanseheving innan vegleiing, sjelesorg, diakoni og sosialpedagogisk arbeid.

- Mange kateketar leiar i dag eit stort fagområde. Tidlegare så leia kateketen fyrst og fremst si eiga undervisningsteneste, i dag er mange kateketar leiarar for pedagogiske «team», og leiar også arbeidet med fagleg utvikling og planar i ein kyrkjelyd eller i eit større fellesrådsområde/prosti. Det vil vere behov for leiarutdanning som dyktiggjer kateketar i å stå i ei slik teneste.

- Vigsling som praksis er blitt styrka dei siste åra, med vigslingsførebuande samling, og krav om liturgiske klede Spørsmål kring kateketyrket som ei livslang teneste, og moglege karrierevegar, har vore ein del av samtalen i desse 50 åra ein har hatt kateketar. Arbeidsgjevarar i begge liner, og kyrkja som heilskap, har eit felles ansvar i å gje gode vilkår til kateketar og andre innan undervisning. Kyrkja sitt behov for dyktige folk innan undervisning, for barn og unge, men også vaksne, er udiskutabel. Kyrkjerådet har varsla ein gjennomgang av kvalifikasjonskrava til dei kyrkjelege profesjonane. I det høvet vil både gamle og nye spørsmål reise seg om kateketyrket i framtida.

Med kyrkjemøtevedtaket i 2015 om undervisningsstillingane i Dnk, vart kateketyrket stadfesta som ei sentral kyrkjeleg teneste. Kyrkjerådet har og varsla ny gjennomgang av kvalifikasjonskrav til alle dei kyrkjelege profesjonane. Katekettenesta er komen for å bli, og eg ser optimistisk på nye 50 år for katekettenesta i Den norske kyrkje til beste for barn og unge i ei ny tid.

\section{LitTERATUR}

Dale, Aasmund. 1994. Læring i kirken: En praktisk kirkedidaktikk. Oslo: IKO-Forlaget Horsfjord/Sørensen/Heiene/Leganger-Krogstad, Holmqvist. 2015. Kompetanse, utdanning og motivasjon. En kartlegging av undervisningstjenesten i Den norske kirke, MF-rapport 1:2015

Kirkerådet. 2002. Evaluering av kvalifikasjonskrav og tjenestekrav for kateketer

Kirkerådet. 2010. Plan for trosopplcering. Gud gir - vi deler 
NOU 2000:26 «... til et åpent liv i tro og tillit». Dåpsopplaring i Den norske kirke, Oslo: Kirke-, utdannings- og forskningsdepartementet.

Minneord, Aasmund Dale: https://www.idunn.no/ttk/2008/01/minneord_aasmund_dale_192727?

Sandsmark, Astrid og Holmqvist, Morten. 2018. Vår trosopplæering? Stab, samarbeid og trosopplaring, MF-rapport 3:2018

Tjenesteordning og kvalifikasjonskrav for kateketer: https://lovdata.no/dokument/ SF/forskrift/2004-11-20-1894

Erfaringsbasert master i kirkelig undervisning ved MF https://www.mf.no/master/ kateket-deltid

Disiplinbasert master i kirkelig undervisning ved MF https://www.mf.no/studier/ kirkelig-undervisning

Nettsiden: Jobb som forandrer Den norske kirke. https://kirken.no/nb-NO/om-kirken/ arbeid-og-utdanning/jobb-som-forandrer/

\section{Vedlegg: Hvordan bli Kateket?}

Hvordan kvalifisere seg til stilling som kateket i Den norske kirke i dag, og hvor studerer man? Her er en kortfattet versjon av noen av mulighetene.

\section{Kvalifikasjonskrav til kateket}

For tilsetting som kateket i Den norske kirke kreves utdanning på masternivå som inneholder minimum 80 studiepoeng kristendom/teologi, 30 studiepoeng relevant pedagogikk/formidlingsfag og 60 studiepoeng praktisk-kirkelige fag med hovedvekt på kateketiske emner. Relevant mastergrad er pedagogikk, kristendomskunnskap/teologi eller kirkelig undervisning/kateketikk. Utdanningen må inneholde veiledet praksis til kateket. Les om Tjenesteordning og kvalifikasjonskrav for kateket her: https://lovdata.no/dokument/SF/ forskrift/2004-11-20-1894

\section{Studiesteder:}

MF Vitenskapelige Høyskole: Erfaringsbasert master i kirkelig undervisning (90 studiepoeng). Studiet er samlingsbasert, og det undervises over 3 år. Master i teologi med studieretning kirkelig undervisning (120 studiepoeng).

VID - Kirkelig utdanningssenter i Nord (KUN): 30 kateketiske studieemner på masternivå. Studiet går over ett år. Les mer om studiet på https://www.vid.no/ studier/praktisk-kirkelig-utdanning/

Teologisk fakultet i Oslo (TF): Master i teologi (120 studiepoeng) med fordypning innenfor kirkelig undervisning.

NLA Høgskolen, Bergen: Master i teologi (120 studiepoeng) med fordypning innenfor kirkelig undervisning (studieprogram master in Theology and Ministry). 